\title{
GROSS NEGLIGENCE AND THE GUEST PASSENGER
}

The common law, before legislative intervention, imposed upon one who undertook to provide for the gratuitous conveyance of another a duty to take care for the safety of his guest. The standard associated with that duty was to take that care which the ordinary or reasonable man would take under similar circumstances. ${ }^{1}$ The duty and standard thus imposed did not vary with the nature of the undertaking to provide the conveyance. They remained constant whether it be a gratuitous undertaking or one for hire or reward. With the onslaught of legislative intervention this position underwent drastic change according to the terms in which the various statutory provisions were phrased.

The most radical change was brought about by those legislatures which saw fit to absolve the driver from any right of action at all by the guest passenger. ${ }^{2}$ Ameliorating provisions have since been substituted in these jurisdictions, ${ }^{3}$ and one jurisdiction has recently gone one step further and repealed its guest statute completely. ${ }^{4}$ By excluding the guest passenger's right of action these legislatures placed all the risk on the guest passenger in all conceivable circumstances.

Less radical though nonetheless severely restrictive changes were effected by the guest statute provisions in the remaining jurisdictions. They limited the guest passenger's right of action to cases where his driver could be shown to be guilty of conduct amounting to "gross negligence or wilful and wanton misconduct". 5 By so doing they preserved the common law duty to take care but the standard of the ordinary and reasonable driver had obviously been relaxed to the prejudice of the guest passenger. Though an absolute assumption of risk was not imposed on the guest passenger by these statutory provisions, some of the risk, namely that conduct falling short of gross negligence or wilful and wanton misconduct, was no doubt to be assumed.

All of the guest statutes which remain in force in Canada today preserve the duty of a driver to take care for the safety of his guest passenger. However, a more relaxed standard is imposed.

Six of the remaining eight jurisdictions which still have guest passenger legislation, restrict the guest passenger's right of action to cases where "gross negligence or wilful and wanton misconduct" can be shown. ${ }^{6}$ One restricts it to cases where "gross negligence" can be shown ${ }^{7}$ while another has limited the guest passenger's action to cases where "wilful and wanton misconduct" is present. ${ }^{8}$

\footnotetext{
' Lygo v. Newbold (1854) 9 Ex. 302 at 305 per Parke B.; Harris v. Perry \& Co. [1917] 2 K.B. 219 at 226 per Collins M.R.; Armand v. Carr [1926] S.C.R. 575 at 581 per Anglin C.J.C.; see contra Moffatt $v$. Bateman 6 Moore N.S. 369 at 377 per Lord Chelmsford-followed in Nightingale v. Union Colliery Co. (1904) 35 S.C.R. 65 at 176 per Nesbitt J.-but distinguished in Ryckman v. The Hamilton Elec. Rwy. Co. \& Wilkinson (1911) 45 S.C.R. 263 at 268 per Duff J.-overruled in Armand v. Carr, supra.

2 This was the effect of the first guest statutory provisions in New Brunswick, Ontario, Alberta and British Columbia-see Table 1 .

3 See Table 1.

- British Columbia-where a no-fault insurance scheme was enacted in 1969 as a result of the recommendation of The Wooton Royal Commission on automobile insurance and compensation to victims of automobile accidents (1966) and in line with the recommendations of the Commission, British Columbia's guest pas. senger legislation was repealed (see Table 1).

s Saskatchewan, Manitoba, Nova Scotia, Prince Edward Island and Newfoundland-see Table 1.

- Alberta, Manitoba, Newfoundland, Nova Scotia, New Brunswick and Prince Edward Island-see Table 1.

7 Ontario-see Table 1. This was the same position taken by the British Columbia legislature until 1969, when they repealed their provision.

s Saskatchewan-see Table 1.
} 
The courts have been burdened with the task of deciding to what extent the legislatures have restricted the common law rights of the guest passenger with respect to the standard of care required to be exercised by his driver in given circumstances under these various provisions. It is accepted that a change in the common law has been effected by the statutes, ${ }^{9}$ but to move towards at least partial appreciation of the exact nature of that change requires a closer look at the treatment received by the phrases "gross negligence", "wilful and wanton misconduct" and "gross negligence or wilful and wanton misconduct" by our courts.

\section{WHAT CONSTITUTES "GROSS NEGLIGENCE"?}

Before embarking on a consideration of the treatment these three phases have received by our courts, it must be remembered, and emphasized, that the phrases are being used to describe a standard of care and are not intended to be referring to any duty to take care. The standard which they impose does not fluctuate with the skill possessed by the host driver 10 nor with the risk faced by a driver bound by that standard. ${ }^{11}$ It is therefore simply a question of fact in each case whether one's actions per se have amounted to gross negligence or not. To this end two separate tests have been developed by our courts; the "very great negligence" test and the "very marked departure" test.

\section{The "Very Great Negligence" Test}

The Supreme Court of Canada in Holland v. City of Toronto ${ }^{12}$ was dealing with the use of the term "gross negligence" in a snow removal statute which exonerated the defendant corporation from liability for injuries suffered as a result of icy sidewalks, "except in case of gross negligence". The plaintiff had slipped and fallen on an icy sidewalk which had been in that condition for two days to the knowledge of one of the defendant's employees. The defendant was found guilty of "gross negligence" and liable for the plaintiff's injuries. Anglin C.J.C. in commenting on the term "gross negligence" in the statute said: ${ }^{13}$

The term 'gross negligence' in this statute is not susceptible of definition. No $a$ priori standard can be set up for determining when negligence should be deemed

"very great negligence"-a paraphrase suggested in Drennan v. City of Kingston 27

S.C.R. 46, which for lack of anything better has been generally accepted.

To say that "gross negligence" is "very great negligence" is obviously not defining it, and the inadequacy of doing so is evident from the words of Anglin C.J.C. quoted above. However, the elements which must be considered in order to determine whether or not there has been "very great negligence" do give some definition to "gross negligence." In the Holland case Anglin C.J.C. said this about those elements:14

The circumstances giving rise to the duty to remove a dangerous condition, including the notice, actual or constructive, of its existence, and the extent of the risk which

${ }^{9}$ Cowper v. Studer (1951) S.C.R. 450 at 461 per Estey J.

10 Which was what the court purported to say was the case in railway transportation cases in B.C. Electric Railway Co. v. Williams (1911) 45 S.C.R. 263 at 268.

"Id. But see contra Ogilvie v. Donkin [1949] I W.W.R. 439; and Gurling v. Howden [1949] I W.W.R. 95.

12 [1927] S.C.R. 242, 59 O.L.R. 628.

" 59 O.L.R. 628 at 634.

1" Id. 
it creates ... the character and the duration of the neglect to fulfill that duty, including the comparative ease or difficulty of discharging it . . . these elements must vary in indefinite degree; and they seem to be important, if not vital, factors in determining whether the fault (if any) ... is so much more than merely ordinary neglect that it should be held to be a very great, or gross, negligence.

What he was saying in effect was that there are two important factors to consider in deciding whether a particular wrongful act is due to "gross negligence" or "ordinary negligence"; knowledge of the risk and the length of time it is negligently not guarded against. If one continues to act negligently in the face of a known risk then, if in the circumstances he does so for an extraordinary length of time, that is gross negligence or "very great" negligence. In the Holland case this is precisely the reasoning the court used in finding "gross negligence" on the part of the defendant corporation. The defendant had knowledge of the icy sidewalk (the risk) yet for two days it did nothing about it.

The Supreme Court of Canada applied the "very great negligence" test in the guest passenger case of Cowper v. Studer. ${ }^{15}$ The court was there faced with the use of the term "gross negligence or wilful and wanton misconduct" as used in Saskatchewan's guest passenger legislation. ${ }^{16}$ The infant plaintiff had been riding in the defendant's automobile at four c'clock in the morning. The roads were icy and the defendant had been approaching a railway crossing at about 35-40 miles per hour when he failed to stop for a train and struck the last car, causing injuries to the plaintiff. In the result the defendant was found liable for the plaintiff's injuries within the terms of Saskatchewan's legislation. In arriving at their decision the court accepted the definition given to "gross negligence" by the Drennan case:17

... until the meaning of the expression is clarified by legislation, the courts admin. istrating Justice must, in my opinion treat the question to be decided . . . as whether or not there has been very great negligence in the circumstances of the particular case.

The court felt that there had been "very great negligence" on the jury's finding that the defendant continued to operate his motor vehicle at too high a speed in approaching the railway crossing on an icy road, knowing full well that he would be unable to stop if a train were to cross.

The "very great negligence" test was applied by the Nova Scotia Supreme Court in the case of Seymour v. Maloney.18 The court was there faced with Nova Scotia's guest passenger legislation which precluded any action unless "gross negligence or wilful and wanton misconduct" was shown. It found the defendant to be guilty of conduct amounting to "gross negligence" in that he was driving at excessive speeds for some length of time while he was intoxicated to a considerable degree. ${ }^{19}$ MacDonald J. in giving his judgment, said: ${ }^{20}$

Imprecise as it may be, we must take it as established that . . . the guest passenger has only a qualified right of action against his negligent driver, viz., for "very

\footnotetext{
is Supra, n.9.

16 The Traffic Act, 1936 S.S. c. 106, s. 8(2)-see Table 1.

17 Per Locke J. at 467; see also Currie J. in Williams and Read v. Brown \& Brown [1955] 4 D.L.R. 454 at 467; and Kerwin J. in Kerr v. Cummings [1953] 2 D.L.R. 1 at 2.

2R [1955] 1 D.L.R. 824.

19 Id. at 838 per MacDonald J.

20 Id. at 830 .
} 
TABLE 1

A SUMMARY OF GUEST PASSENGER LEGISLATION IN CANADA AND RELATED STATUTES

\begin{tabular}{|c|c|c|c|}
\hline & Alberta & $\begin{array}{l}\text { Britioh } \\
\text { Columbia }\end{array}$ & Manitoba \\
\hline 1. Original Legislation & $\begin{array}{l}(1934) \text { S.A. } \\
\text { C. } 62 \text { S. } 9\end{array}$ & $\begin{array}{l}\text { (1938) S.B.C. } \\
\text { C. } 42 \text { S. } 3\end{array}$ & $\begin{array}{l}(1935) \text { S.M. } \\
\text { C. } 20 \text { S. } 10\end{array}$ \\
\hline 2. Present Legislation & $\begin{array}{l}\text { (1967) S.A. } \\
\text { C. } 30 \text { S. } 211(1)\end{array}$ & $\begin{array}{l}\text { Repealed } \\
\text { (1969) S.B.C. } \\
\text { C. } 20 \text { S. } 12\end{array}$ & $\begin{array}{l}\text { (1970 R.S.M. } \\
\text { C. H60 S. } 145\end{array}$ \\
\hline $\begin{array}{l}\text { 3. Complete Exclusion of Guest Passenger's Right } \\
\text { of Action }\end{array}$ & Until 1941 & No & No \\
\hline 4. Action Limited to Cases of 'Gross Negligence' & No & Until Repeal & No \\
\hline $\begin{array}{l}\text { 5. Action Limited to Cases of 'Wilful and Wanton } \\
\text { Misconduct' }\end{array}$ & No & No & No \\
\hline $\begin{array}{l}\text { 6. Action Limited to Cases of 'Gross Negligence or } \\
\text { Wilful and Wanton Misconduct' }\end{array}$ & Since 1941 & No & Yes \\
\hline 7. Driving for Hire or Reward Excepted & Since 1941 & Yes & Yes \\
\hline $\begin{array}{l}\text { 8. Supplementary Provision Under Contributory } \\
\text { Negligence Act }\end{array}$ & $\begin{array}{l}\text { (1955) R.S.A. } \\
\text { C. } 56 \text { S. } 4\end{array}$ & $\begin{array}{l}\text { Repealed } \\
\text { (1970) S.B.C. } \\
\text { C. } 9 \text { S. } 1\end{array}$ & $\begin{array}{l}\text { (1970) R.S.M. } \\
\text { C. T90 S. } 5\end{array}$ \\
\hline $\begin{array}{l}\text { 9. Passenger Liability Insurance Under Insurance } \\
\text { Act Optional }\end{array}$ & $\begin{array}{l}\text { (1955) R.S.A. } \\
\text { C. } 159 \text { S. } 296(d)\end{array}$ & $\begin{array}{l}\text { (1969) S.B.C. } \\
\text { C. } 11 \text { S. } 233\end{array}$ & $\begin{array}{l}\text { (1970) R.S.M. } \\
\text { C. } 140 \text { S. } 247\end{array}$ \\
\hline
\end{tabular}

great negligence" [Cowper v. Studer, supra]; and since even gross negligence is a breach of duty, the duty owing by a driver in such cases, is simply the marginal duty to refrain from very great negligence.

These words emphasize that the duty to act without gross negligence implies a duty to act with a lower standard of care than that required of the reasonable man. It does import a duty, though slight, to take care, but it does not require that ordinary care be taken.

The foregoing authorities have made some effort to define what "gross negligence" is in relation to particular factual situations. It is because the factual situation must be known before one can say whether particular conduct is gross negligence or ordinary negligence, that it is so difficult to give a universal definition of gross negligence. However, the so-called "very great negligence" test does offer some direction. The test as to whether or not one appreciates the risk one is faced with is still the reasonable man as pointed out by Anglin C.J.C. in Holland v. City of Toronto. ${ }^{21}$ Beyond that the standard of the reasonable man is dropped. The duty to guard against that risk is not to take ordinary care (which is what a "reasonable man" must do), but rather it is to take at least slight care. In deciding whether slight care has been taken in a particular factual situation, it is relevant to consider the length of time during which the risk went unguarded against. If the risk is allowed to operate for an extraordinary length of time then that will be considered very great (or gross) negligence.

To the extent of defining what will be "gross negligence" in a particular factual situation the "very marked departure" test (discussed below) is of little more help than the "very great negligence" test. However, the former test has been more widely accepted by recent authorities, probably because its terms of reference are far wider. 


\begin{tabular}{|c|c|c|c|c|c|}
\hline ' $\begin{array}{c}\text { New } \\
\text { Brunswick }\end{array}$ & Newfoundland & Nova Scotia & Ontario & $\begin{array}{l}\text { Prince Edward } \\
\text { Island }\end{array}$ & Saskatchewan \\
\hline $\begin{array}{l}\text { (1934) A.N.B. } \\
\text { C. } 20 \text { S. 52(1) }\end{array}$ & $\begin{array}{l}(1951) \text { S.N. } \\
\text { No. } 95 \text { S. } 80\end{array}$ & $\begin{array}{l}\text { (1932) N.S.L. } \\
\text { C.6S. } 183\end{array}$ & $\begin{array}{l}\text { (1935) S.O. } \\
\text { C. } 26 \text { S. } 11\end{array}$ & $\begin{array}{l}\text { (1949) L.P.E.I. } \\
\text { C. } 17 \text { S. } 17\end{array}$ & $\begin{array}{l}(1936) \text { S.S. } \\
\text { C. } 106 \text { S. } 8(2)\end{array}$ \\
\hline $\begin{array}{l}\text { (1955) N.B.A. } \\
\text { C. } 13 \text { S. 242(1) }\end{array}$ & $\begin{array}{l}\text { (1962) S.N. } \\
\text { No. } 82 \text { S. } 220(1)\end{array}$ & $\begin{array}{l}\text { (1967) R.S.N.S. } \\
\text { C. } 191 \text { S. } 223\end{array}$ & $\begin{array}{l}\text { (1966) S.O. } \\
\text { C. } 64 \text { S. } 20\end{array}$ & $\begin{array}{l}\text { (1964) L.P.E.I. } \\
\text { C. } 14 \text { S. } 275\end{array}$ & $\begin{array}{l}\text { (1965) R.S.S. } \\
\text { C. } 377 \text { S. } 168(2)\end{array}$ \\
\hline Until 1951 & No & No & Until 1966 & No & No \\
\hline No & No & No & Since 1966 & No & No \\
\hline No & No & No & No & No & $\begin{array}{l}\text { Yes } \\
\text { Since } 1951\end{array}$ \\
\hline Since 1951 & Yes & Yes & No & Yes & Until 1951 \\
\hline Yes & Yes & Yes & Since 1966 & Yes & Yes \\
\hline $\begin{array}{l}(1961-62) \text { S.N.B. } \\
\text { C. } 16 \text { S.3 }\end{array}$ & $\begin{array}{l}\text { (1952) R.S.N. } \\
\text { C. } 159 \text { S. } 8\end{array}$ & $\begin{array}{l}\text { (1967) R.S.N.R. } \\
\text { C. } 54 \text { S. } 3\end{array}$ & $\begin{array}{l}\text { (1966) S.O. } \\
\text { C. } 98 \mathrm{~S} .1\end{array}$ & No & $\begin{array}{l}\text { (1965) R.S.S. } \\
\text { C. } 91 \text { S.8 }\end{array}$ \\
\hline $\begin{array}{l}\text { (1952) R.S.N.B. } \\
\text { C. } 113 \text { S. } 205 \text { (d) }\end{array}$ & $\begin{array}{l}\text { (1968) S.N. } \\
\text { N. 36 S. 26(9)(a) }\end{array}$ & $\begin{array}{l}\text { (1967) R.S.N.S. } \\
\text { C. } 148 \text { S. } 98(1)\end{array}$ & $\begin{array}{l}\text { (1960) R.S.O. } \\
\text { C. } 190 \text { S. } 216 \text { (d) }\end{array}$ & $\begin{array}{l}\text { (1966-67) C.P.E.I. } \\
\text { C. } 28 \text { S. 196(a) }\end{array}$ & $\begin{array}{l}\text { (1965) R.S.S. } \\
\text { C. } 409 \text { S. } 39(1 \times d)\end{array}$ \\
\hline
\end{tabular}

\section{The Very Marked Departure Test}

The so-called "very marked departure test" arises out of the decision of the Supreme Court of Canada in McCulloch v. Murray.22 In that case the respondent had sued the appellant for injuries she had received while riding as a guest without payment in the appellant's motor vehicle. At trial the appellant had been found guilty of "gross negligence" (which was required to be shown under Nova Scotia's guest passenger legislation) and the jury found such gross negligence to consist of the appellant's "reckless driving". The reported case does not give any more detail than that about the accident but the court's discussion of Nova Scotia's guest statute is the point worth noting.

Nova Scotia's guest passenger legislation ${ }^{23}$ provided that a guest passenger's right of action against his driver was limited to cases where "gross negligence or wilful and wanton misconduct" on the part of the driver was shown. In deciding what standard of conduct was implied by that phrase, Duff C.J., in giving the majority judgment, said: ${ }^{24}$

All these phrases, gross negligence, wilful and wanton misconduct, imply conduct in which, if there is not a conscious wrongdoing, there is a very marked departure from the standards by which responsible and competent people in charge of motor cars habitually govern themselves.

These words are the very marked departure test. In substance it is no different than the very great negligence test discussed above. It too, emphasizes that the standard of care by which the conduct of a motor vehicle operator is to be measured is a lower standard than that associated with the reasonable man. A mere departure from the standards of the reasonable man would not be sufficient, though that is all that is required to constitute negligence at common law.

As with the very great negligence test (as outlined by Anglin C.J.C.

\footnotetext{
22 [1942] S.C.R. 141.

${ }^{23}$ See Table 1.

24 McCulloch v. Murray, supra, n. 22 at 143.
} 
in Holland v. City of Toronto ${ }^{25}$ ) the very marked departure test emphasizes that the length of time during which the risk is knowingly allowed to operate (against one to whom the duty to act with this lower standard is owing), is directly proportionate to the degree of negligent conduct. This was the point made by Tysoe J.A. in the guest passenger case of Hagg v. Bohnet. ${ }^{26}$ In applying the very marked departure test to the facts before him, he said: 27

... unless the carelessness goes substantially beyond mere casual inadvertence or momentary forgetfulness or thoughtlessness, it does not amount to gross negligence.

Thus in the guest passenger case of Dunnington v. Bailey ${ }^{28}$ the defendant driver's action of going through a red light was found not to go "substantially beyond mere casual inadvertence or momentary forgetfulness or thoughtlessness". ${ }^{29}$ The defendant's inaction had lasted for some five or six seconds.

Where the very marked departure test differs from the very great negligence test is in its reference to both "gross negligence" and "wilful and wanton misconduct". Except for Cowper v. Studer, which will be discussed below, those authorities which developed the "very great negligence" test were concerned primarily with giving some useful meaning to the term "wilful and wanton misconduct" as used either jointly with "gross negligence" (as for example in Alberta's guest passenger legislation) or alone (as in Saskatchewan's guest passenger legislation). Duff C.J., by grouping both of these terms together and giving an all-encompassing definition of the standard of conduct to which they referred, provided a definition which could be applied under any guest passenger legislation. It is probably because of this that the "very marked departure" test has been widely accepted by the majority of recent decisions under guest passenger legislation. ${ }^{30}$

\section{3. "Criminal Negligence" and the Standard of Care Imposed By Guest Passenger Legislation}

It is clear from the discussion by the courts of both the "very great negligence" and "very marked departure" tests that guest passenger legislation imposes a much lower standard of care on the motor vehicle operator than did the common law. But a rather surprising, if not shocking, result is arrived at if one considers whether a guest passenger in order to succeed in an action against his driver need show conduct amounting to criminal negligence. Does the requirement that the guest passenger must show "gross negligence" (as required by Ontario's guest passenger legislation) or "gross negligence or wilful and wanton misconduct" (as required by Saskatchewan's guest passenger legislation) on the part of his driver in order to succeed go so far as to require that conduct as culpable as criminal negligence must be shown?

\footnotetext{
25. Supra, n. 12.

28 (1962) 38 W.W.R. 679.

${ }^{27}$ Id. at 685 .

20 (1965) 52 W.W.R. 22.

29 Id. at 30 per Aikens $\mathrm{J}$.

30 It has been cited with approval in: Scardina v. LaRoche [1950] 2 W.W.R. 22; Hagg v. Bohnet (1962) 38 W.W.R. 679; Wruck v. Kruzuk (1962) 37 W.W.R. 68; Dunnington v. Bailey (1965) 52 W.W.R. 22; Schwartz v. Norbury (1965) 49 D.L.R. 740; Mabey v. Robertson (1969) 70 W.W.R. 23; Kozack v. Dobson \& C.N.R. (1970) 72 W.W.R. 193; Dahl v. Saydack (1970) 73 W.W.R. 133; and Lardner v. Canada Permanent Trust (1970) 71 W.W.R. 759.
} 
Under the Criminal Code it is provided that everyone is criminally negligent who in doing anything or omitting to do anything that it is his duty to do, shows a wanton or reckless disregard for the lives and safety of others. ${ }^{31}$ It is then made an offence to operate a motor vehicle with criminal negligence ${ }^{32}$ or to exhibit dangerous driving. ${ }^{33}$ As to the standard of conduct which will result in a conviction under these sections, the Quebec Court of Appeal in Goodfellow v. . $^{34}$ said: ${ }^{35}$

\begin{abstract}
It would be unwise to attempt a precise definition of "dangerous driving". However, since one must identify the type of driving which attracts criminal as well as civil sanction, I would say that the offence of s. 221(4) requires an element that need not be established when only civil responsibility is involved and that this element is the deliberate incurring of risks that render almost inevitable the consequences contemplated by the Code-the threat of injury or damage to persons or property. Once this element is established the difference between the criminal negligence and the dangerous driving [sections] of the Code becomes one of degree.
\end{abstract}

This would seem to indicate that criminal negligence requires a flagrant and deliberate disregard of the circumstances such that it is inevitable that serious harm or damage will result. What difference there is between such conduct and conduct which allows a continued neglect of a dangerous situation (which is what the courts in developing the "very great negligence" test and the "very marked departure" test seem to have said would constitute "gross negligence" or "gross negligence or wilful and wanton misconduct"), is hard to appreciate. It is even more difficult to see a distinction between the elements of criminal negligence and the standard of conduct implied by the term "wilful and wanton misconduct". That term too, does connote a deliberate intent.

Notwithstanding the apparent equivalence of the standard of conduct amounting to criminal negligence and that amounting to civil liability under guest passenger legislation, the court in Cowper v. Studer, ${ }^{36}$ discussed above, went to some length to negate any such equivalence.

It will be recalled that the court in Cowper v. Studer was dealing with Nova Scotia's guest passenger legislation, which gave a guest passenger a right of action against his driver only in cases where "gross negligence or wilful and wanton misconduct" could be shown. In deciding what standard of conduct was imported by these words, the court held that the two components of the phrase, "gross negligence [or]" and "wilful and wanton misconduct" were severable: the latter implying subjective conduct on the part of the driver, while the former referred to something "entirely apart from what the driver thought or intended". ${ }^{37}$ They were therefore saying that "gross negligence" did not require subjective intent and therefore where that term was used by itself it would not be taken to be equivalent to criminal negligence. A similar conclusion was reached by the Supreme Court of British Columbia in Gurling v. Howden. ${ }^{38}$ In his judgment in Cowper v. Struder, Rand J. added that where the two components were used together, as was the

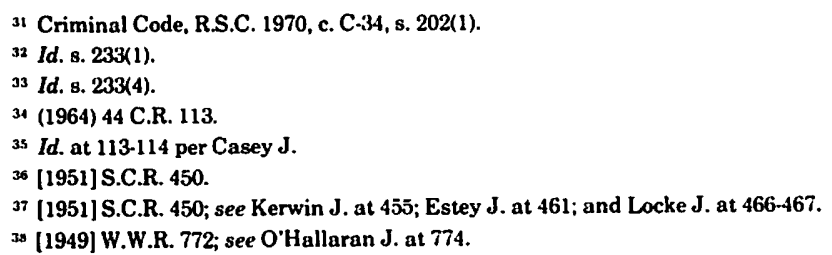


case in the legislation before the court, it was not to be taken that they referred to conduct amounting to criminal negligence. ${ }^{39}$

Cowper v. Struder is therefore authority for saying that when guest passenger legislation prescribes that in order for a guest passenger to maintain an action against his driver he must show either "gross negligence" or "gross negligence or wilful and wanton misconduct" it is not required to show conduct amounting to criminal negligence. However, it is not like authority where, as in Saskatchewan, guest passenger legislation requires that a guest passenger must show "wilful and wanton misconduct" in order to maintain his action against his driver. According to Cowper v. Studer "wilful and wanton misconduct" implies subjective conduct on the part of the driver and furthermore it implies conduct more reprehensible than "gross negligence". ${ }^{40}$ Surely if such was the case there would be little, if any, difference between such conduct and criminal negligence. If so then Saskatchewan's guest passenger legislation imposes almost no duty at all upon the guest passenger's driver and would seem to put a very heavy burden on the guest passenger in an action for damages for injuries suffered.

In decisions under Saskatchewan's guest passenger legislation, it has not been intimated that criminal negligence, per se, need be shown. In Kozak v. Dobson \& C.N.R., ${ }^{41}$ the Saskatchewan Queen's Bench applied the "very marked departure" test of $M c C u l l o c h$ v. Murray (discussed above). The plaintiff was a guest passenger in a motor vehicle being operated by the defendant, which collided with a passenger train at a railway crossing. The roads were icy and the defendant was operating his motor vehicle between thirty and thirty-five miles per hour. As he approached the railway crossing he was faced with six flashing red lights but did not reduce his speed and struck the train. MacPherson J. in finding the defendant guilty of "wilful and wanton misconduct" said: ${ }^{\mathbf{2}}$

The defendant's negligence consisted of his failure to see what there was to be seen.

This was considerably more than momentary inattention. He displayed no vigilance whatsoever.

Whether MacPherson J. meant by these words that the defendant's conduct amounted to criminal negligence is a matter of interpretation. It is a fine distinction to be made, if one is to be made at all, between calling such conduct wilful and wanton or labelling it criminal negligence.

Though the Justices sitting on the Cowper v. Struder decision were rather explicit in negating the implication that criminal negligence is required to import liability under guest passenger legislation, it is difficult to see how they arrived at that conclusion. What can be said is that in their attempt to negate the implication they emphasized the degree to which guest passenger legislation has qualified the guest passenger's common law rights.

It should, by now, be evident to the reader that the duty of care owed by a motor vehicle operator to his guest passenger has been severely relaxed by guest passenger legislation. Whereas at common law he was required to exercise due and reasonable care in all circumstances, under the various guest passenger statutes he need not use

\footnotetext{
39 [1951] S.C.R. 456.

so Id. at 463 per Estey J.

4 (1970) 72 W.W.R. 193.

12 Id. at 197.
} 
much more care, if any at all, than does the criminally negligent driver. Looked at from the view of the guest passenger, guest passenger legislation creates in the motor vehicle operator one of our most privileged tortfeasors. At common law the host driver's defences, as against his guest passenger, to an action in negligence were that his passenger had been volen's and/or contributorily negligent. Neither of these defences are affected by guest passenger legislation, ${ }^{43}$ and in addition an extremely heavy burden of proof is placed on the guest passenger to import flagrant misconduct to his driver. To all other users of the highway, the motor vehicle operator owes the duty to exercise reasonable care in all circumstances, yet because of guest passenger legislation the guest passenger runs the risk of his driver deviating from the standard of conduct implied by that duty. From the guest passenger's point of view the motor vehicle operator is not unlike Dr. Jekyll and Mr. Hyde.

\section{THE DISFAVOUR OF THE COURTS FOR GUEST PASSENGER LEGISLATION}

The common law of negligence has in general moved towards a theory of stricter liability over the past century, adapting to a changing social need. ${ }^{44}$ The law of occupier's liability and the employer-employee relationship are but two examples of this phenomenon. The modern cases of Donaghue v. Stevenson ${ }^{45}$ and Hedley Byrne \& Co. v. Heller and Partners ${ }^{46}$ represent the basic trend.

Before the introduction of guest passenger legislation, the motor vehicle operator was liable in negligence to his guest passenger. With the introduction of that legislation. his liability was made less strict even though the tendency at law suggests that the move should have been in the opposite direction.

However, despite the presence of guest passenger legislation, the Canadian courts have in guest passenger cases gone to great lengths to follow the trend towards stricter liability. In so doing, one could say that they have, so far as it is possible for them to do so, voiced their disapproval for guest passenger legislation. They have done this in three ways: by excluding specific classes of "guest passengers" from the application of the legislation; by finding gross negligence on negligent facts; and by making a liberal application of the rule of evidence of res ipsa loquitur to the proof of gross negligence.

\section{Excluding Specific Classes of Guest Passengers}

A guest passenger is defined both directly and indirectly by guest passenger legislation. He is defined directly as a "person transported by the owner or driver of a motor vehicle as a guest without payment." 47 Those statutes which use this definition except from their application a passenger who is being driven for hire. The guest passenger is defined indirectly by that guest passenger legislation which deems all pas-

\footnotetext{
43 See Clancy v. Toronto General Trusts Corporation (1950) 58 Man. R. 430 at 440.

" For a comprehensive look at the direction the common law of negligence has taken in the twentieth century see Millner, Negligence in Modern Law (1967).

45 [1932] A.C. 562

46 [1964] A.C. 465, [1963] 2 All E.R. 575.

${ }^{47}$ E.g. Alberta's guest passenger legislation S.A. 1967, c. 30, s. 211(1); and cf. Manitoba, Newfoundland, New Brunswick, Nova Scotia and Prince Edward Island-see Table 1.
} 
sengers "guest passengers" except those who are passengers in a motor vehicle which is "ordinarily used for passengers for hire or gain".48

Prima facie, it would appear that a guest passenger is one of two distinct creatures depending upon what jurisdiction he is in. Under the first mentioned statutes he will be a "guest passenger" only if he does not "pay" his host for the transportation. As such the courts are confronted with a problem equally difficult to solve as is the determination of whether or not a particular lawful visitor on an occupier's premises has conferred "economic benefit" upon his host. Under the latter class of guest passenger legislation the question of whether or not a passenger has "paid" his host driver is irrelevant. If he is riding in a motor vehicle which is "ordinarily used for passengers for hire or gain" then irrespective of the question of payment he will not be a guest passenger. ${ }^{49}$ Likewise, if he is not riding in such a motor vehicle, then ipso facto he is a guest passenger whether or not he has made payment for his ride. It is in this latter case where the two classes of statutes conflict; under the first class of statutes the question of "payment" appears to be relevant, while under the others the question of "payment" need not even be considered. Under both types of statutes the courts have gone to some length to exclude from the application of the legislation those who would appear prima facie to fall within the definitions outlined above.

In Dorosz \& Dorosz v. Koch ${ }^{50}$ the infant plaintiff had suffered serious injuries while being conveyed to her home after performing her baby-sitting duties for the defendant. The Ontario Court of Applea decided that the Ontario guest passenger legislation did not extend to cover employer-employee relationships, ${ }^{51}$ and found that the infant plaintiff was still in the course of her duties during the conveyance. ${ }^{52}$ This would seem to be a very liberal interpertation of the Ontario statute in that, as discussed above, it would appear to exclude from its application only those who are being conveyed in a vehicle ordinarily used for the conveyance of passengers for hire or gain. The defendant's vehicle certainly did not come within that definition.

The Manitoba Court of Appeal made a similar exception in Tycholitz v. Crop, ${ }^{53}$ as did the B.C. Supreme Court in Gemmel v. Wilson \& Penner.54 In the latter case, the court held that as there was a benefit or advantage flowing to the defendant Wilson in conveying the plaintiff, the conveyance was one for "hire" or "gain" and therefore Gemmel was not a guest within the terms of the British Columbia statute. ${ }^{55}$ Like the Ontario statute, the B.C. statute only excluded from its operation those who were being conveyed in a motor vehicle ordinarily used to convey passengers for hire or gain. Wilson's car would not seem to have fallen within the exception on a strict interpretation.

Other persons who have been deemed not to be guest passengers

\footnotetext{
4s E.g. Saskatchewan's guest passenger legislation R.S.S. 1965, c. 337, s. 168(2); and cf. Ontario, and British Columbia $\rightarrow$ see Table 1 .

4" In accordence with B.C. Electric Rwy. Co. v. Wilkinson (1911) 45 S.C.R. 263.

so [1961] O.R. 442

s) Id. at 443 per Schatz J.

32 Id.

s3 [1936] 2 W.W.R. 416; appeal from [1936] 2 W.W.R. 222.

st (1951-52) 4 W.W.R. 337.

ss Id. at 342 per Farris C.J.S.C.
} 
under the various statutes are workers being conveyed in their foreman's car as part of the foreman's duty, ${ }^{56}$ an owner of goods being conveyed in a motor vehicle in which his goods are being carried for reward,,$^{57}$ and an owner of a motor vehicle being towed gratuitously in his own car. ${ }^{58} \mathrm{~B}$. V. Richardson has made a useful survey of exceptions made to the guest statutes in the United States. ${ }^{59}$

The effect of all of these exceptions made by the courts is to restore the "guest passenger" to the common law position of being owed the standard of ordinary reasonable care. The lengths to which the courts have gone to do this, it is submitted, indicates their dissatisfaction with guest passenger legislation.

\section{Finding "Gross Negligence" on "Negligent" Facts}

The courts have, on occasion, found a driver's actions to be tantamount to "gross negligence or wilful and wanton misconduct" when on a fair and reasonable interpertation of his conduct it could not be said that he was anymore than simply negligent. That is, the courts have found themselves faced with a set of facts which at best make out a case of negligent conduct on the part of a guest passenger's driver, and therefore without more the guest passenger's action is ended in face of the requirements of guest passenger legislation. Nonetheless, the courts have simply said that they find the defendant driver's conduct to be grossly negligent, enabling the guest passenger to recover.

In the case of Kozack v. Richter and Dobson and C.N.R.60 the Saskatchewan Court of Queen's Bench found the defendant driver guilty of "wilful and wanton misconduct" for failing to observe flashing red lights at a railway crossing. His omission resulted in injuries to the plaintiff who was riding as a guest passenger in the defendant's motor vehicle. MacPherson J. said of the defendant's conduct: ${ }^{61}$

The defendant's negligence consisted of his failure to see what there was to be seen. This was considerably more than momentary inattention. He displayed no vigilence whatsoever.

To say that a "failure to see what there was to be seen" is tantamount to "wilful and wanton misconduct" 62 is an odd judicial pronouncement. Such a failure would seem to be precisely what is required to constitute simple negligence. Simply because the failure lasted for some five to six seconds" ${ }^{63}$ would not seem to make it "considerably more than momentary inattention". It would take some research to find a case where a driver's inattention had lasted for any shorter period in failing to observe a traffic control device.

The Supreme Court of British Columbia was faced with a very similar situation in Dunnington v. Bailey.64 There, the defendant driver had failed to observe a red light against her at a traffic intersection which

so Girling v. Courtier (1957) 22 W.W.R. 1.

${ }^{37}$ Wandaleer v. Dawson [1936] 3 W.W.R. 478; cf. Lygo v. Newbold, supra, n. 1 where Parke B. under English common law in a similar factual situation found that ordinary reasonable care was owing.

ss Freeborn v. Bungar [1943] 1 W.W.R. 589.

35 Richardson, The Guest Law, (1935) 13 Can. Bar Rev. 685.

${ }^{60}$ (1970) 72 W.W.R. 193.

61 Id. at 197.

62 Which is the requirement for liability under Saskatchewan's guest passenger legislation-see Table 1.

${ }^{63}$ Supra, n. 62 at 197.

64 (1965) 52 W.W.R. 22. 
resulted in a collision with another motor vehicle, causing injuries to herself and her guest passenger (the plaintiff). The British Columbia guest passenger legislation required "gross negligence" to be shown before a motor vehicle operator could be found liable for injuries to his guest passenger. ${ }^{65}$ Aikens $\mathrm{J}$. in giving the majority judgment in the case found that this requirement was not satisfied on the facts before the Court: 66

Even though this lack of attention lasted for some five to six seconds I do not think this lack of attention... goes substantially beyond mere casual inadvertance or momentary forgetfulness or thoughtlessness.

This finding is quite opposite to that of MacPherson J. in the Kozack case discussed above. The case of Martin v. Jatkowski and Drier, ${ }^{67}$ wherein the defendant merely failed to observe a stop sign, is another example of a finding of "gross negligence on negligent facts". The Kozack and Martin cases are, it is submitted, examples of the courts' disfavour of the guest passenger legislation.

\section{Res Ipsa Loquitur, and the Proof of Gross Negligence}

The courts' eagerness to find gross negligence on negligent facts is better exemplified by the recent acceptance of res ipsa loquitur to the proof of gross negligence under guest passenger legislation. ${ }^{6}$ By accepting the applicability of this rule of evidence to such cases, the courts have gone a long way in negating the effect of the legislation.

All of the guest passenger statutes in Canada expressly provide that the onus of proof in a guest passenger-driver situation shall be on the guest passenger to show that his driver's conduct has amounted to gross negligence or wilful and wanton misconduct. ${ }^{69}$ This puts the host driver in the relatively favourable position of being liable only where his guest passenger shows "gross fault".

By accepting the application of res ipsa loquitur to the proof of the driver's "gross fault" the burden of proof prima facie placed on the guest passenger by the guest statutes is at once shifted to the host driver, thus defeating the express legislative provision. The result is that the host driver is no longer faced with "gross fault liability" but with something close to "strict liability", that being the direct effect of res ipsa loquitur on an action in negligence. ${ }^{70}$ The guest passenger's likelihood of succeeding in an action against his host driver is thereby greatly enhanced, contrary to the spirit in which guest passenger legislation was introduced.

The Walker v. Coates ${ }^{71}$ case was an appeal from the Alberta Appellate Division to the Supreme Court of Canada. The plaintiff had been a guest passenger in a motor vehicle being operated by the defendant, who was killed in the accident. The evidence showed only that the vehicle had been travelling at a speed of about 60 m.p.h.

\footnotetext{
6.5 See Table 1.

B6 (1965) 52 W.W.R. 22 at 30.

67 (1968) 65 W.W.R. 725.

${ }^{68}$ By the Supreme Court of Canada in Walker v. Coates (1968) 64 W.W.R. 449. Yet the application of the maxim to the proof of gross negligence was rejected in Clancy v. The Toronto General Trusts Corp. (1951) 58 Man. R. 430 at 434 per Major J.

${ }^{69}$ See Table 1.

7o See Millner, Negligence in Modern Law 89 (1967) and Fleming. An Introduction to the Law of Torts 156 (1967).

31 (1968) 64 W.W.R. 449.
} 
on a good paved highway, when for some reason it veered diagonally across the highway and struck a road sign heavily secured by rock and concrete. The plaintiff had been asleep at the time of the accident and could offer no explanation. Ritchie $J$. in commenting on the plaintiff's plea of res ipsa loquitur, said: ${ }^{72}$

If the rule of res ipsa loquitur is accepted in cases where proof of "negligence" is in issue, I can see no logical reason why it should not apply with equal force when the issue is whether or not there was "very great negligence" provided, of course, the facts of themselves afford reasonable evidence in the absence of explanation by the defendant, that the accident arose as a result of a very marked departure from the standards to which Sir Lyman Duff referred to in the McCulloch case.

and further: ${ }^{73}$

... there are circumstances here showing a greater probability that the accident may have happened from gross negligence than from the reasons suggested by the defendant.

The rule of res ipsa loquitur is accepted in cases where the proof of "negligence" is an issue, especially in motor vehicle accident cases.74 But, contrary to the Walker v. Coates decision, there do seem to be logical reasons why it should not apply where "gross negligence" is in issue.

The maxim was first accepted as a rule of evidence by Earl C.J. in Scott v. London and St. Katherine Dock Co. ${ }^{75}$ where the plaintiff had been injured when a sack of flour fell from the defendant's warehouse window and struck him on the head. Earl C.J. phrased the rule in these words: ${ }^{76}$

Where the thing is shown to be under the management of the defendant or his servants and the accident is such as in the ordinary course of things does not happen if those who have the management use proper care, it affords reasonable evidence, in the absence of an explanation by the defendant that the accident arose from want of care.

Put in more simple terminology the plea of res ipsa loquitur means that a prima facie case of negligence is created in favor of the plaintiff simply by the fact that the accident or mishap occurred, and it is left to the defendant to offer an explanation equally consistent with no negligence on his part. By accepting the rule of res ipsa loquitur to the proof of gross negligence in the Walker v. Coates case, the definition offered by Erle C.J. is modified to read as follows: ${ }^{77}$

Where the thing is shown to be under the management of the defendant or his servants and the accident is such as in the ordinary course of things does not happen if those who have management use at least slight care, it affords reasonable evidence, in the absence of an explanation by the defendant, that the accident arose from a gross want of care.

In the Walker case the motor vehicle in which the plaintiff and defendant were riding was "under the management of the defendant" and the defendant was unable to give a reasonable explanation of

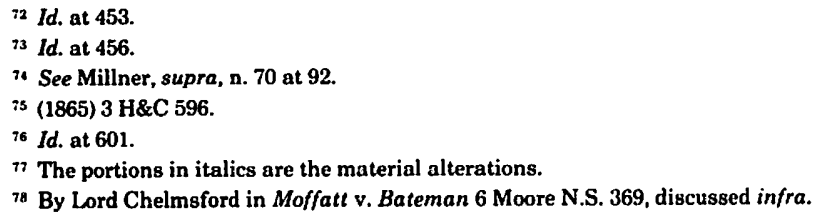


how the accident occurred. Therefore, in that motor vehicles do not usually veer across highways and strike road signs if those in control of them use proper care, the facts in the Walker case made out a prima facie case of negligence against the defendant. But can it be said that on those facts the defendant was "grossly negligent" as Ritchie J. concluded?

It was recognized as far back as $1869^{78}$ that there is nothing more usual than for accidents to happen in driving without any want of care or skill on the part of the driver. ${ }^{79}$ Similarily, there is nothing more usual, given the proper factual situation (as for instance the facts in the Walker case) for accidents to happen in driving with the want of reasonable care or skill on the part of the driver but without his gross want of care or skill. In the former case the rule of res ipsa loquitur is properly applied. To apply it in the latter case is an over-extension of the rule in that to create a case of gross negligence or wilful and wanton misconduct some direct evidence relating to the defendant driver's conduct must be available. The mere fact that the accident has happened is no evidence of his conduct either express or implied; it is at best evidence only that there has been a lack of reasonable care. To say that the mere fact that the accident has occurred is prima facie evidence of the defendant driver's gross negligence or wilful and wanton misconduct, is to say that there is evidence of the defendant's actions. Once this has been said, then the rule of res ipsa loquitur cannot be applied, because the application of that rule and the existance of provable acts are mutually exclusive. ${ }^{80}$

It is submitted that the acceptance of the rule of res ipsa loquitur by the court in Walker v. Coates was merely done to circumvent the onerus burden put on the guest passenger by the guest statutes. The Walker case has been followed in subsequent decisions.81 As such it is submitted that this is another example of the courts expressing their disfavour with guest passenger legislation.

The judiciary has not been alone in expressing its discern with the continued existence of guest passenger legislation. More direct criticisms have been levelled by numerous writers. ${ }^{82}$ In the United States there has been in recent years numerous efforts to secure the repeal of various guest statutes. ${ }^{83}$ In 1965 there were attempts to repeal in ten states while in 1967 there were nine similar attempts. ${ }^{84}$ Only one state, Connecticut, has succeeded in repealing its guest statute. ${ }^{85}$ In Canada, British Columbia repealed its guest passenger legislation in 1969.86

$79 \mathrm{Id}$. at 380 , in refusing to allow the plaintiff to plead res ipsa loquitur.

Mabey v. Robertson (1969) 70 W.W.R. 23 at 32 per Porter J.A.

81 Id. Where the defendant's vehicle had been operated by him on the wrong side of the road, for approximately 400 feet before coming into collision with another vehicle; Lardner v. Canada Permanent Trust Co. (1970) 71 W.W.R. 759 where the defendant had operated his motor vehicle on the wrong side of the road for some 300 feet before colliding with a stationary vehicle.

*2 Linden, 42 Can. Bar Rev. 337: Gibson, (1968) 6 Alta. L. Rev. 211; McCruer, 1966 Osgoode Hall L.J. 54; Kushner, (1958) 30 Man. B.N. 57; Linden, (1962) 4 Can. Bar Rev. 685; White, (1933-34) 20 Virginia L. Rev. 329; Prosser, Law of Torts 191 (3d ed.); James, 8 Law of Torts $961-962$ (1956); Special Committee on Automobile Accident Reparation. Report of American Bar Association (1969) 19.

ss Report of American Bar Association, supra, n. 82 at 87.

B. Id.

os Id.

so See Table 1. 


\section{CONCLUSION}

It is evident that little, if any, support can now be found for the continued enforcement of guest passenger legislation in Canada. In fact the evidence appears to be overwhelmingly in favour of repealing all such legislation and returning the guest passenger to common law principles. The evidence is there in the form of judicial discontent, persistent attempts, some recently successful, at legislative repeal and the comment of legal commentators since the time of the original guest statutes pointing to the injustice created by the legislation.

The motor vehicle has never been so much a necessity for transportation as it is today in Canada and the United States. Gratuitous rides are given to millions of people every day, not out of some latent gratuitous spirit in motor vehicle drivers, but out of necessity. The fact that any particular conveyance is given gratuitously more than likely never enters the mind of either the motor vehicle operator or his passengers. Even less likely is the knowledge of either party that the motor vehicle operator is not bound to exercise due and reasonable care in providing a gratuitous conveyance. Both driver and passenger probably have in mind that the operation of the vehicle will be carried out in a reasonable manner under all circumstances and that if the operator is negligent in his operation of the vehicle and the guest passenger is thereby injured, then the driver will be liable to compensate him accordingly.

There is no presumption on the part of the parties themselves that the guest passenger is taken to assume the risk of the driver's ordinary negligence. Then why should the law presume so for them? The courts both before and after enactment of the guest statutes expressed no desire to make such a prima facie presumption. The trend of the common-law in other areas speaks against making such a presumption.

If the guest passenger is to assume any part of the risk of motor vehicle transportation then the common law offers the proper framework within which to import such an assumption in the proper circumstances. The doctrine of volenti non fit injuria is applied by the common law for such purposes, and it affords reasonable protection to motor vehicle operators, and for that matter their liability insurers, against an improper award of damages to guest passengers. If a guest passenger continues to voluntarily accept his transportation in knowledge of a known risk and is subsequently injured as a result of that risk then he will fail in any action against his driver.

Guest passenger legislation is a prime example of what M.A. Millner has referred to as "tiresome anomalies and lacunae which have succumbed neither to judicial reform nor to legislative action".87 It is paradoxical that the guest passenger should remain in so unprivileged a position vis-â-vis his host driver when both the judiciary and legislators are imposing stricter liability for negligence in other legal relationships. The injustice created by guest passenger legislation is blatently obvious, yet despite several attempts to draw attention to that fact it remains in force in eight Provinces. 
The judiciary can only go so far to guard against legislative injustice. British Columbia's recent step in repealing its guest passenger legislation is an example which hopefully will be soon followed by the remaining Provinces.

-JOHN R. SINGLETON* 